\title{
Vyhlášky úradov verejného zdravotníctva ako právny predpis
}

\author{
Kukliš, P.* \\ KUKLIŠ, P.: Vyhlášky úradov verejného zdravotníctva ako právny predpis. Právny obzor, \\ 104, 2021, č. 2, s. $141-154$. \\ The ordinances of public health authorities as generally binding legal act. The article \\ deals with the ordinances of the Public Health Office and of regional public health \\ authorities as a new type of generally binding legal act. The subject of criticism is the way \\ in which the law empowered the Public Health Office and regional public health authorities \\ - as state budget organizations - to issue generally binding ordinances. The way in which \\ this legislation is published is also criticized.
}

Key words: pandemic, constitutionality, legislation, the Public Health Office, regional public health authorities, ordinances

\section{1}

Súčasná pandemická situácia výrazným spôsobom preveruje schopnosti politikov, verejných činitel'ov, odborníkov z množstva oblastí l'udskej činnosti, ale aj schopnosti jednotlivcov i komunít v postavení objektu činnosti (ale i nečinnosti) osôb a inštitúcií zodpovedných (v rozličných oblastiach a na rôznej úrovni) za riešenie tejto situácie. Súčasné obdobie sa vyznačuje výraznou, viac-menej oprávnenou kritikou viacerých právnych aspektov zápasu s pandémiou.

Predmetom kritiky je aj neujasnenost' používaných niektorých právnych, resp. neprávnych predpisov z aspektu ústavnosti a zákonnosti, osobitne opatrení na predchádzanie ochoreniam a opatrení vo vybraných prípadoch ohrozenia zdravia úradov verejného zdravotníctva.

\section{1}

Verejná ochrankyňa práv ako najzásadnejší problém identifikovala skutočnost', že niektoré opatrenia Úradu verejného zdravotníctva Slovenskej republiky (d’alej len Úrad verejného zdravotníctva) mali pôsobnost' na celom území Slovenskej republiky, a preto ich čast' odbornej verejnosti považovala za všeobecne záväzný právny predpis. V zmysle platnej právnej úpravy je prieskum všeobecne záväzného právneho predpisu na ústavnom súde pre fyzické a právnické osoby nedostupný; návrh podl’a čl. 125 ústavy môžu podat' len aktívne legitimované subjekty. Ked’že však spomínaný článok ústavy predpokladá len prieskum takého právneho predpisu, ktorý vydal ústredný orgán štátnej správy, je prieskum opatrení Úradu verejného zdravotníctva, ktorý nie je ústredným orgánom štátnej správy, z abstraktnej kontroly ústavnosti vylúčený.

Ak by bolo opatrenie Úradu verejného zdravotníctva správnym aktom, treba ho považovat' za akýsi „hybridný“ správny akt, pretože zaväzuje neurčitý počet adresátov, t. j.

JUDr. Peter K u k 1 i š, CSc., Ústav štátu a práva Slovenskej akadémie vied, Bratislava. Tento príspevok vznikol v rámci projektu APVV-19-0090 Právna metodológia pre dobu právneho pluralizmu. 
nie je individuálne vymedzený a ich adresátom nie je individuálna fyzická alebo právnická osoba. Takýto správny akt náš právny poriadok explicitne nepozná a pre jeho špecifickost' si vyžaduje aj špecifickú právnu úpravu, ktorá v takých prípadoch zabezpečí relevantnú právnu ochranu. V̌̌eobecná správna žaloba podl’a § 177 Správneho súdneho poriadku preskúmava individuálne správne akty. Umožňuje $\mathrm{v}$ individuálnom prípade domáhat' sa ochrany subjektívnych práv proti rozhodnutiu orgánu verejnej správy alebo opatreniu orgánu verejnej správy, avšak výsledkom (v prípade, že je žalobca v konaní úspešný) môže byt' len zrušenie napadnutého rozhodnutia, či opatrenia súdom. Súd nemôže, čo by v prípade hybridného správneho aktu bolo potrebné, svojím rozhodnutím potvrdit' či suspendovat' individuálny účinok opatrenia Úradu verejného zdravotníctva voči konkrétnej osobe, nemôže rozhodnút' o nezákonnosti postupu orgánu štátu pri realizácii opatrenia Úradu verejného zdravotníctva. Súd môže len zrušit' opatrenie ako celok, čo v prípade opatrenia Úradu verejného zdravotníctva môže viest' až k absurdnej situácii, v ktorej súd s regionálnou pôsobnost'ou zruší opatrenie s platnost'ou na celom území Slovenskej republiky.

Za významný nedostatok týchto potenciálnych prostriedkov nápravy verejná ochrankyňa práv považuje aj to, že negarantujú osobe, ktorá je adresátom opatrenia Úradu verejného zdravotníctva, urýchlené konanie, ktoré je v tomto prípade nevyhnutné, ak má byt' právna ochrana reálna. Pri opatrení, ktorého prijatie reflektuje na vel'mi rýchlo sa meniacu pandemickú situáciu a ktorého platnost' trvá v zásade niekol'ko týždňov až mesiacov, kým ho nenahradí iné opatrenie, lehota na poskytnutie adekvátnej právnej ochrany nesmie presiahnut' niekol'ko dní, nanajvýš týždňov. Preto verejná ochrankyňa zastáva názor, že súčasná právna úprava neumožňuje realizovat' súdnu kontrolu opatrení Úradu verejného zdravotníctva a vytvára právnu neistotu, ktorá môže byt' kedykol'vek a voči komukol'vek zneužitá bez akejkol'vek kontroly. ${ }^{1}$

\section{2}

Generálny prokurátor zdôraznil v upozornení na nezákonný postup Úradu verejného zdravotníctva, že porušenie zákona súvisí predovšetkým s nedostatkom vecnej pôsobnosti tohto úradu na vydávanie opatrení po vyhlásení mimoriadnej situácie a po vyhlásení núdzového stavu, ako aj s právnou formou týchto opatrení. Úrad verejného zdravotníctva nepatrí medzi ústredné orgány štátnej správy, ani medzi ostatné ústredné orgány štátnej správy.

Úrad verejného zdravotníctva vyhlásením mimoriadnej situácie a núdzového stavu stráca oprávnenie prijímat' akékol'vek opatrenia súvisiace s krízovou situáciou. Naopak, pri riešení krízových situácií a ich následkov sa predpokladá intenzívna spolupráca Úradu verejného zdravotníctva s kompetentnými orgánmi, súvisiaca najmä s odbornou zdravotnou pôsobnost'ou tohto úradu. Ním prijaté opatrenia však nemôžu dosahovat' intenzitu a dosah (personálny aj územný) opatrení, na ktorý oprávňuje režim špeciálnych zákonov vládu a ústredné orgány štátnej správy. Nie je vylúčené, že by takéto opatrenia mo-

\footnotetext{
${ }^{1}$ Informácia o 38. zasadnutí Rady vlády Slovenskej republiky pre l'udské práva, národnostné menšiny a rodovú rovnost', https://rokovania.gov.sk/RVL/Material/25497/1 (19. január 2021).
} 
hol vydávat' úrad verejného zdravotníctva na vykonávanie opatrení vlády, a to na základe jednoznačného zmocnenia.

Generálny prokurátor neakceptoval tvrdenie, že prijatiu opatrení v záujme naliehavej potreby ochrany verejného záujmu ustupuje požiadavka na úpravu procesného postupu ich vydávania. Takéto tvrdenie nemá oporu v zákone, pričom právna forma prijatých opatrení, ako aj spôsob ich doručenia, resp. vyhlásenia sú sporné. Opatrenia úradu verejného zdravotníctva možno charakterizovat' ako opatrenia orgánu verejnej správy sui generis, ktoré vykazujú znaky normatívneho aktu (všeobecne vymedzený okruh adresátov, vyhlasovanie a účinnost'), ale prevažuje v nich rozmer individuálneho správneho aktu, pretože obsahujú riešenie konkrétnej administratívnej veci, t. j. konkrétne určený predmet, súvisiaci s určitou situáciou.

Vyhlásenie mimoriadnej situácie a núdzového stavu sprevádzalo prijatie množstva opatrení, ktoré bezprecedentným spôsobom zasiahli do základných práv a slobôd fyzických a právnických osôb. Prokuratúra nespochybňuje vážnost' situácie (najmä aktuálnej situácie šírenia ochorenia COVID-19) a ani potrebu prijatia opatrení, ktorých legitímnym ciel'om je ochrana verejného zdravia obyvatel'stva, ktoré je vážne ohrozené v dôsledku pandémie ochorenia COVID-19.

V zmysle zákona č. 355/2007 Z. z. Úrad verejného zdravotníctva disponuje právomocou pri vzniku epidémie nariadit' opatrenia pri ohrození verejného zdravia, faktom však zostáva, že v prípade vyhlásenia mimoriadnej situácie a núdzového stavu sú štátne orgány povinné postupovat’ podl’a špeciálnych zákonov, upravujúcich krízovú situáciu.

S poukázaním na zákonom vymedzenú právomoc na nariadenie opatrení pri ohrození verejného zdravia, odvodenie pôsobnosti na vydávanie opatrení aj v čase mimoriadnej situácie a núdzového stavu, pri ohrození verejného zdravia II. stupňa podl’a $\S 48$ ods. 4 zákona č. 355/2007 Z. z. považuje prokuratúra za prekročenie rozsahu pôsobnosti úradu verejného zdravotníctva, ktoré spôsobuje nezákonnost’ vydaných opatrení (nie však ich nulitu). ${ }^{2}$

\section{1}

Odstránenie kritizovaného stavu zákonodarca riešil zákonom č. 286/2020 Z. z., ktorým sa mení a dopíňa zákon č. 355/2007 Z. z. o ochrane, podpore a rozvoji verejného zdravia a o zmene a doplnení niektorých zákonov v znení neskorších predpisov a ktorým sa menia a dopĺn̆ajú niektoré zákony. Ustanovenia tohto zákona - §59b ods. 1 až 3 - netradične upravujú všeobecne záväzný právny predpis, ktorým sa nariad’ujú opatrenia na predchádzanie ochoreniam a opatrenia vo vybraných prípadoch ohrozenia zdravia.

Ak je potrebné nariadit' opatrenia podl'a $\S 12$ alebo $\S 48$ ods. 4 [...] nariad'uje ich ministerstvo zdravotnictva [...] úrad verejného zdravotníctva [...] alebo regionálny úrad verejného zdravotníctva [...] všeobecne záväzným právnym predpisom (odsek 1).

${ }^{2}$ Bližšie Upozornenie prokurátora na nezákonný postup orgánu verejnej správy, č. VI/3 Gd 174/20/100016 , z 29. septembra 2020. 
$\mathrm{Na}$ všeobecne záväzné právne predpisy vydávané podl'a odseku 1 ministerstvom zdravotníctva sa vztahuje osobitný právny predpis o tvorbe a vyhlasovaní právnych predpisov; ${ }^{3}$ tento predpis sa nevztahuje na všeobecne záväzné právne predpisy vydávané podl'a odseku 1 úradom verejného zdravotníctva a regionálnym úradom verejného zdravotnictva (odsek 2).

Všeobecne záväzný právny predpis úradu verejného zdravotníctva a regionálneho úradu verejného zdravotnictva vydávaný podl'a odseku 1 sa označuje názvom vyhláška a nadobúda platnost' dňom vyhlásenia vo Vestniku vlády Slovenskej republiky (odsek 3).

\section{2}

Dôvodová správa v tejto súvislosti uvádza, že prebiehajúca pandémia ochorenia Covid-19 odhalila niektoré nedostatky vo formálnych ustanoveniach pri vydávaní opatrení orgánov verejného zdravotníctva. Najväčšou nejasnost'ou je právna povaha opatrení Úradu verejného zdravotníctva, spôsob ich prípravy a najmä vyhlasovania. Úrad verejného zdravotníctva svojimi „opatreniami“ podl’a § 12 zákona č. 355/2007 Z. z. podstatným spôsobom zasahuje do každodenného života, ba dokonca obmedzuje základné práva a slobody. Napriek tomu platný zákon nijakým spôsobom neupravuje podmienky nadobudnutia platnosti týchto aktov ani podmienky ich publikácie. Okrem toho platná úprava neupravuje podrobnejšie ani právnu formu týchto aktov, a preto ústavný súd - pri absencii takejto úpravy - dospel k záveru, že má íst' o tzv. hybridné akty.

Jasnou právnou kvalifikáciou týchto právnych aktov ako všeobecne záväzných právnych predpisov sa jednak vyjasní ich postavenie v právnom poriadku, ked’že sa budú môct' stat' právnym základom konania všetkých štátnych orgánov. Okrem toho sa vyjasní postup a miera ich skúmania, ked’že ich bude možné skúmat' podl'a čl. 125 ods. 1 písm. d) ústavy pre nesúlad s ústavou, ústavnými zákonmi, medzinárodnými zmluvami a inými nadradenými právnymi predpismi, a to na návrh subjektov upravených v čl. 130 ústavy.

V dôvodovej správe sa d’alej uvádza, že ak orgány verejného zdravotníctva rozhodujú o nariadení opatrení podl'a $\S 12$, resp. $§ 48$ ods. 4 inak než voči jednotlivo určenej osobe, ich akty sa nijako nelíšia od všeobecne záväzných právnych predpisov, ked’že sa týkajú určitého územia alebo druhovo určených osôb. Ide teda o úplne všeobecné vymedzenie adresátov tejto právnej normy, ktorým sa v nej ukladajú povinnosti (izolácia, registrácia cez e-karanténu a pod.). Z uvedených dôvodov sa v odseku 1 navrhuje ustanovit', že v týchto prípadoch orgány verejného zdravotníctva nariad’ujú potrebné opatrenia vo forme všeobecne záväzného právneho predpisu. Autori návrhu zákona tvrdia, že z $§ 1$ písm. f) zákona č. 355/2007 Z. z. vyplýva, že „orgány verejného zdravotníctva“ sú „orgány štátnej správy na úseku verejného zdravotníctva“. Podl'a čl. 123 ústavy sú všetky orgány štátnej správy oprávnené vydávat' na vykonanie zákona všeobecne záväzné právne predpisy, ak sú na to splnomocnené zákonom. Ustanovenie $\S 59 \mathrm{~b}$ ods. 1 bude teda splnomocňovat’ orgány verejného zdravotníctva na vydanie týchto všeobecne záväzných

${ }^{3}$ Zákon č. 400/2015 Z. z. o tvorbe právnych predpisov a o Zbierke zákonov Slovenskej republiky a o zmene a doplnení niektorých zákonov v znení neskorších predpisov. 
právnych predpisov, ktorými nariadia jednotlivé potrebné opatrenia podla $\S 12$, resp. $\S 48$ ods. 4.

\section{3}

Pozoruhodné je i prechodné ustanovenie zákona (§ 631), podl’a ktorého „Opatrenia úradu verejného zdravotnictva a regionálnych úradov verejného zdravotníctva vydané $v$ súvislosti so širením ochorenia COVID-19 podl'a § 12 alebo § 48 ods. 4 do nadobudnutia účinnosti tohto zákona sa považujú odo dňa účinnosti tohto zákona za vyhlášky podl'a § 59 b tohto zákona a zostávajú v platnosti a účinnosti nasledujúcich 15 dní po nadobudnutí účinnosti tohto zákona, ak ich orgán, ktorý ich vydal, nezruši skôr. “

Dodatočná konvalidácia vydaných opatrení v tejto vypätej situácii je zrejme opodstatnená (in dubio mitius). Záhadnou je 15-dňová lehota, ktorá evokuje zvláštnu formu derogácie týchto opatrení. Dôvodová správa k tomuto ustanoveniu lakonicky uvádza, že sa určuje na prechodný čas, počas ktorého zostanú v platnosti opatrenia úradu verejného zdravotníctva a regionálnych úradov verejného zdravotníctva vydané pred dňom nadobudnutia účinnosti novej právnej úpravy.

\section{1}

V citovanom § 59b ods. 1 zákonodarca „Úrad verejného zdravotníctva“ a „regionálny úrad verejného zdravotníctva“ fakticky transformuje aj na orgány štátnej správy.

Nemožno súhlasit' s týmto názorom, najmä s neopodstatnenou ústavnoprávnou „skratkou“, uvedenou v osobitnej časti dôvodovej správy, podl’a ktorej z § 1 písm. f) zákona č. 355/2007 Z. z. vyplýva, že „orgány verejného zdravotníctva“ sú „orgány štátnej správy na úseku verejného zdravotníctva“.

Ustanovenie § 1 písm. f) zákona č. 355/2007 Z. z. znie: „Tento zákon ustanovuje opatrenia orgánov štátnej správy na úseku verejného zdravotníctva (d’alej len orgány verejného zdravotníctva) pri ohrozeniach verejného zdravia." Možno mat' opodstatnené pochybnosti o takto formulovanej legislatívnej skratke. Jej základom je totiž termín/pojem „opatrenie“ a jediným možným riešením, pri serióznom dodržiavaní legislatívnej techniky, je legislatívna skratka „opatrenie“, a nie „orgány verejného zdravotníctva“. Preto je problematické jednoznačne tvrdit' - bez d’alších náležitostí - , že „orgány verejného zdravotníctva“ sú „orgány štátnej správy na úseku verejného zdravotníctva“.

Ústava Slovenskej republiky (ústava) je v tomto smere rigoróznejšia: „Ústredné orgány štátnej správy a miestne orgány štátnej správy sa zriad’ujú zákonom (čl. 122). “ Regionálne úrady verejného zdravotníctva možno, z hl'adiska vel'korysého prístupu, $\mathrm{v}$ istom zmysle považovat' za kvázi miestne orgány štátnej správy. Úrad verejného zdravotníctva, v rámci dikcie čl. 122 ústavy, však nemožno považovat’ ani za kvázi ústredný orgán štátnej správy (tým je ministerstvo zdravotníctva), ani za kvázi miestny orgán štátnej správy (tým je regionálny úrad verejného zdravotníctva).

Úrad verejného zdravotníctva je rozpočtová organizácia štátu s pôsobnost'ou pre územie Slovenskej republiky ( $\$ 5$ ods. 1) a regionálne úrady verejného zdravotníctva sú 
rozpočtové organizácie štátu zapojené finančnými vzt’ahmi na rozpočet ministerstva ( 66 ods. 1 zákona č. 355/2007 Z. z. o ochrane, podpore a rozvoji verejného zdravia).

Táto skutočnost' nie je výnimočná, rovnako napr. Rada pre vysielanie a retransmisiu je právnická osoba so sídlom v Bratislave; pri výkone štátnej správy v oblasti vysielania, retransmisie a poskytovania audiovizuálnych mediálnych služieb na požiadanie má postavenie orgánu štátnej správy s celoštátnou pôsobnost'ou v rozsahu vymedzenom týmto zákonom a osobitnými predpismi (§ 4 ods. 3 zákona č. 308/2000 Z. z. o vysielaní a retransmisii). Na tomto mieste je vhodné podotknút', že Rada pre vysielanie a retransmisiu nemá právomoc vydávat' všeobecne záväzné právne predpisy.

Inak je to v prípade Národnej banky Slovenska. Táto finančná inštitúcia je právnickou osobou so sídlom v Bratislave (§ 1 ods. 2 zákona č. 566/1992 Zb. o Národnej banke Slovenska). „Národná banka Slovenska v rozsahu svojej pôsobnosti vydáva všeobecne záväzné právne predpisy, ak to ustanovuje tento zákon alebo osobitný zákon; všeobecne záväzné právne predpisy Národnej banky Slovenska sa vyhlasujú v Zbierke zákonov Slovenskej republiky" ( 1 ods. 3 prvá veta zákona o Národnej banke Slovenska). Pôvodné ustanovenie o právotvornej kompetencii Národnej banky bolo formulované inak: „Pri vydávaní všeobecne záväzných právnych predpisov v rozsahu ustanovenom týmto zákonom má Národná banka Slovenska postavenie ako ministerstvá a iné orgány štátnej správy podl'a čl. 123 Ústavy Slovenskej republiky. Národná banka Slovenska vydáva opatrenia vyhlasované v Zbierke zákonov a rozhodnutia v rozsahu ustanovenom osobitnými predpismi . " Táto formulácia by mohla byt' inšpiráciou na riešenie problémov tohto druhu.

\section{2}

Citovaný $\S 59 b$ ods. 2 o ochrane, podpore a rozvoji verejného zdravia (č. 286/2020 Z. z.) ustanovuje, že zákon č. 400/2015 Z. z. o tvorbe právnych predpisov a o Zbierke zákonov Slovenskej republiky ${ }^{5}$, sa nevzt’ahuje na všeobecne záväzné právne predpisy vydané podl'a odseku 1 úradom verejného zdravotnictva a regionálnym úradom verejného zdravotníctva". V prípade regionálneho úradu verejného zdravotníctva by to azda mohlo byt' pochopitel'né vzhl'adom na istú analógiu s vyhláškami miestnych orgánov štátnej správy. Výhrady možno mat' $\mathrm{k}$ tvorbe právnych predpisov Úradom verejného zdravotníctva. Tieto predpisy výrazným spôsobom stvárňujú právne pomery fyzických osôb i právnických osôb. V drvivej väčšine zasahujú do sféry základných práv a slobôd. Zároveň územná pôsobnost' týchto predpisov je spravidla celoštátna. Právny poriadok rešpektuje mimoriadnu situáciu v právnej normotvorbe. „Ak nastanú mimoriadne okolnosti, najmä ohrozenie l'udských práv a základných slobôd alebo bezpečnosti, [...] v prípade vyhlásenia núdzového stavu [...] ustanovenia § 8 až 10 sa pri procese tvorby právnych predpisov nemusia použit"“ (§ 27 ods. 1 zákona o tvorbe právnych predpisov

\footnotetext{
${ }^{4}$ Pôvodné znenie tohto ustanovenia bolo zmenené na základe čl. 56 ods. 1 ústavného zákona č. 90/2001 Z. z., ktorým sa mení a dopíňa Ústava Slovenskej republiky č. 462/1992 Zb. v znení neskorších predpisov.

${ }^{5}$ Názov zákona je nepresný, pretože tento zákon neupravuje tvorbu právnych predpisov na úrovni subjektov územnej samosprávy a orgánov miestnej štátnej správy.
} 
a Zbierke zákonov Slovenskej republiky), t. j. ustanovenia o portáli, predbežnej informácii, verejnom vypočutí a pripomienkovom konaní.

\section{3}

Bolo uvedené, že traktovaný právny predpis sa označuje názvom vyhláška a nadobúda platnost' dňom vyhlásenia vo Vestníku vlády Slovenskej republiky (§ 59b ods. 3). Zákonodarca sa zjavne inšpiroval zákonom o tvorbe právnych predpisov v Zbierke zákonov a zákonom č. 180/2013 Z. z. o organizácii miestnej štátnej správy (§ 5). K názvu tohto právneho predpisu azda nemožno mat' výhrady, najmä preto, že označenie (termín) „opatrenie“ by nad’alej komplikovalo situáciu. Samotný pojem „opatrenie“ patrí k najrozsiahlejším polysémom v našom právnom poriadku. Jeho rozpätie je vel'mi široké: od opatrenia ako všeobecne záväzného právneho predpisu cez opatrenie priameho zákroku až po predbežné opatrenie rôzneho charakteru. ${ }^{6}$ Odlišné vymedzenie rovnakého pojmu $\mathrm{v}$ rôznych právnych predpisoch je $\mathrm{v}$ rozpore s požiadavkami stálosti pojmoslovia, jednoty a bezrozpornosti, ako aj zrozumitel'nosti právneho poriadku, čo nekorešponduje s koncepciou právneho štátu.

\section{4}

Pochybnosti možno mat' o publikovaní vyhlášok úradov verejného zdravotníctva ako všeobecne záväzných právnych predpisov - vo Vestníku vlády Slovenskej republiky (Vestník vlády). Štátnym publikačným nástrojom Slovenskej republiky na vyhlasovanie právnych predpisov je Zbierka zákonov Slovenskej republiky [§ 12 ods. 1 písm. a) zákona č. 400/2015 Z. z. o tvorbe právnych predpisov a o Zbierke zákonov Slovenskej republiky a o zmene a doplnení niektorých zákonov]. Ustanovenie $§ 15$ tohto zákona „O všetkom, čo bolo v Zbierke zákonov vyhlásené, sa má za to, že dňom vyhlásenia sa stalo známym každému, koho sa to týka " - majúce charakter nevyvrátitel'nej právnej domnienky - je ojedinelé z hl'adiska ostatných publikačných nástrojov tohto druhu. ${ }^{7}$

Zbierka zákonov Slovenskej republiky má normatívny základ v ústave (čl. 87 ods. 4 a 128; napr. aj čl. 7 ods. 2 a 5, čl. 87 ods. 2, čl. 98 ods. 1, čl. 120 ods. 3 a čl. 123). Vestník vlády bol zriadený uznesením vlády Slovenskej republiky č. 145 z 26. marca 2014 k návrhu zásad vydávania Vestníka vlády Slovenskej republiky. ${ }^{8} \mathrm{~V}$ zmysle čl. 1 sa v tomto Vestníku uverejňujú (i) vyhlášky okresných úradov a iných miestnych orgánov štátnej správy, (ii) oznámenia o vydaní smerníc a iných vnútorných predpisov, ktorými minister-

${ }^{6}$ Bližšie napr. Slovník veřejného práva československého. Svazek I. Reprint původního vydání. Praha : Eurolex Bohemia, 2000, s. 36 a nasl.; STAŠA, J. Rozhodnutí a/nebo opatření jako „předmet“ obecné správní žaloby. In Nový Správny súdny poriadok : návrh. Bratislava : Univerzita Komenského, Právnická fakulta 2014, s. 42 a nasl.; STAŠA, J. Nad významy termínu „opatřeni'“ v předpisech správního práva. In Právní rozhledy, 2017, č. 22, s. 777 an; HAVELKOVÁ, M. Opatrení nie je nikdy dost' (3. čast' série blogov k metódam a formám činnosti verejnej správy). In Comenius blog, 2020. https://comeniusblog.flaw.uniba.sk/2020/05/29/opatrenieje-nikdy-dost-3-cast-serie-blogov-k-metodam-a-formam-cinnosti-verejnej-spravy/ (6. február 2021).

${ }^{7}$ Tak aj napr. MÁČAJ, L. - CHROPOVSKÝ, P. Niekol'ko úvah o právnych aspektoch opatrení v boji proti pandémii Covid-19, prednáška, Naděje právní vědy 2020 - Právní věda v praxi : mezinárodní konference mladých vědeckých pracovníků konaná on-line dne 27. listopadu 2020, s. 7.

${ }^{8}$ https://rokovania.gov.sk/RVL/Material/10680/1 (19. január 2021). 
stvá a ostatné ústredné orgány štátnej správy riadia a kontrolujú výkon štátnej správy uskutočňovaný okresnými úradmi, inými miestnymi orgánmi štátnej správy, vyššími územnými celkami a obcami, (iii) oznámenia a iné opatrenia, ak tak ustanovuje všeobecne záväzný právny predpis, (iv) oznámenia a iné opatrenia ministerstiev a ostatných ústredných orgánov štátnej správy určené pre okresné úrady, iné miestne orgány štátnej správy, ako aj vyššie územné celky a obce pri výkone štátnej správy.

Uverejňovanie vyhlášok ako všeobecne záväzných právnych predpisov miestnych orgánov štátnej správy a smerníc a iných vnútorných predpisov ústredných orgánov štátnej správy upravuje uvedený zákon č. 180/2013 Z. z. o organizácii miestnej štátnej správy ( 5 a 6). Tento právny predpis je zrejmé jediný, ktorý upravuje uverejňovanie niektorých právnych predpisov a interných normatívnych aktov vo Vestníku vlády. ${ }^{9}$

Otázne je, do akej miery môže zákon č. 286/2020 Z. z., ktorým sa mení a dopĺn̆a zákon č. 355/2007 Z. z. o ochrane, podpore a rozvoji verejného zdravia, dodatočne konvalidovat' neprávny základ Vestníka vlády ako publikačného nástroja na vyhlasovanie právnych predpisov.

\section{5}

Bolo už zdôraznené, že traktované predpisy radikálnym spôsobom stvárňujú právne pomery fyzických osôb i právnických osôb a výrazne, z hl'adiska početnosti i úrovne ingerencie štátu, zasahujú do sféry základných práv a slobôd. Je zjavné, že Vestník vlády je temer neznámy publikačný nástroj na rozdiel od Zbierky zákonov Slovenskej republiky. Túto skutočnost' je žiaduce naliehavo brat' do úvahy práve pri edícii právnych predpisov súvisiacich so súčasnou pandémiou. Je vhodné sa vystríhat' čo i len náznakov evokujúcich „,bezprávie“ tyrana Dionýza, ktorý svoje zákony nechával vyvesovat' tak vysoko, aby ich občania nemohli čítat'. ${ }^{10}$

Spôsob publikácie právneho predpisu je znakom civilizovaného prístupu k právu a ukážkou, ako sa štát stavia k občanom. ${ }^{11}$ Vo všeobecnosti sa uznáva zásada, že neznalost' práva neospravedlňuje (ignorantia iuris non excusat) a že nik sa nemôže ospravedlňovat' za porušenie práva tým, že ho nepoznal. V tomto prípade však nejde o fingovanú znalost' právnej normy, ale o požiadavku jej všeobecnej znalosti (t. j. všeobecnej prístupnosti) a o zodpovednost' za jej neznalost', resp. o riziko z jej neznalosti. ${ }^{12}$

Všeobecná prístupnost' právnych predpisov na tejto úrovni spoluutvára právnu istotu subjektov práva. Je hrubým porušením právnej istoty ako imanentnej súčasti koncepcie

\footnotetext{
${ }^{9}$ Ustanovenie $\S 19$ ods. 3 zákona č. 374/1996 Z. z., ktorým sa mení a dopĺn̆a zákon č. 278/1993 Z. z. o správe majetku štátu (Opatrenia zriad'ovatel'ov, ktorými sa upravujú dispozičné oprávnenia správcov.... sa uverejňujú vo Vestniku vlády Slovenskej republiky.) bolo zrušené.

${ }^{10}$ HODÁS, M. Dopady normotvorby Európskej únie na normotvorbu členského štátu Európskej únie z hladiska legislativnej techniky a normotvorných procesov. Bratislava : Univerzita Komenského, Právnická fakulta 2018, s. 118; PLACHÝ J. Úloha Sbírky zákonů při publikaci právních aktů moci výkonné. In Časopis pro právní védu a praxi, 2015, č. 2, s. 153, marg. pozn. 4.

${ }^{11}$ Tak aj CVRČEK, F. - NOVÁK, F. a kol. Legislativa. Teoretická východiska a problémy. Plzeň : Aleš Čeněk, 2017, s. 55; bližšie napr. PLACHÝ, J., dielo cit. v pozn 10, s. 153-161.

${ }^{12}$ KNAPP, V. Teorie práva. Praha : C. H. Beck 1995, s. 74-75.
} 
právneho štátu (čl. 1 ods. 1 ústavy), ak by bol občan postihnutý sankciou za porušenie právnej normy, ktorú nemohol spoznat', pretože mu nebolo umožnené, aby sa s jej obsahom zoznámil. ${ }^{13}$

Je otázka, či možno za porušenie takto koncipovaného právneho predpisu oprávnene sankcionovat', resp. či vyhlášky úradov verejného zdravotníctva nemajú charakter imperfektných právnych predpisov. Imperfektné právne normy vyvolávajú vážny teoretický problém, ktorý je spojený so znakom vynútitel’nosti právnej normy. ${ }^{14}$

\section{5}

Je opodstatnené zastávat' stanovisko, že všeobecne záväzný právny predpis vydaný ministerstvom alebo iným orgánom štátnej správy sa stáva prameňom práva vyhlásením alebo oznámením v Zbierke zákonov Slovenskej republiky v deň, ked' nadobudne účinnost', ${ }^{15}$ hoci súčasná právna úprava Zbierky zákonov Slovenskej republiky je odlišná oproti už neúčinnému zákonu č. 1/1993 Z. z. o Zbierke zákonov Slovenskej republiky.

V tejto súvislosti je vhodné sa zamysliet' nad eventuálnou novelizáciou $§ 18$ ods. 2 prvej vety zákona č. 400/2015 Z. z. o tvorbe právnych predpisov a o Zbierke zákonov Slovenskej republiky v tom zmysle, že nielen opatrenia, ale aj vyhlášky miestnych orgánov štátnej správy - uverejnené vo Vestníku vlády v úplnom znení - sa vyhlasujú oznámením o jeho vydaní v Zbierke zákonov Slovenskej republiky. ${ }^{16}$ To znamená, že vyhlášky miestnych orgánov štátnej správy by sa v Zbierke zákonov vyhlasovali v rovnakom právnom režime ako opatrenia preto, aby vyhlášky tohto druhu mohli byt' charakterizované ako prameň práva.

Rovnako ako v prípade opatrení by v Slov-lexe boli sprístupnené i úplné znenia vyhlášok a konsolidovaných znení novelizovaných vyhlášok miestnych orgánov štátnej správy, ktoré by malo, prirodzene, výlučne informatívny charakter [analógia s ustanovením $\S 18$ ods. 5) zákona o tvorbe právnych predpisov a o Zbierke zákonov Slovenskej republiky]. Zdvojené publikovanie týchto osobitne významných vyhlášok by nesporne prispelo k požadovanej prístupnosti „pandemických“ právnych predpisov.

Zrejme bude vhodné primerane upravit' i dodatočnú konvalidáciu vydaných vyhlášok obdobne, ako je to upravené v citovanom $\S 631$ zákona č. 286/2020 Z. z. (3.3.).

Do úvahy prichádzajú aj alternatívy, že zákon o tvorbe právnych predpisov a o Zbierke zákonov Slovenskej republiky osobitne upraví náležitosti Vestníka vlády, resp. problematika Vestníka vlády bude schválená samostatným zákonom.

Opodstatnenost' výhrad k súčasnej právnej úprave pertraktovanej problematiky „potvrdzujứ české právne predpisy - zákon č. 35/2021 Sb. o Sbírce právních předpisuu územních samosprávných celků a některých správních úradů a zákon č. 36/2001 Sb., kterým se měni některé zákony v souvislosti s prijetím zákona o Sbírce právních předpisư územních samosprávných celkư a některých správních úřadio schválené 19. januára 2021.

\footnotetext{
13 Tamže, s. 207.

${ }^{14}$ Tamže, s. 156.

${ }^{15}$ Tak aj DRGONEC, J. Ústava Slovenskej republiky: teória a prax. Bratislava : C. H. Beck, 2015, s. 1290.

${ }^{16}$ Bližšie https://www.slov-lex.sk/vykonavacie-predpisy.
} 
Ve Sbírce právních předpisů se

a) vyhlašují obecně závazné vyhlášky a nařizení vydané územními samosprávnými celky [...] a právní predpisy vydané správními úřady, stanovi-li tak jiný právní předpis [...] a b) zveřejňuji akty stanovené tímto zákonem, které vznikaji při výkonu působnosti územních samosprávných celků nebo v souvislosti s tímto výkonem [...] (§ 1 ods. 1 druhá veta).

Právní předpis územního samosprávného celku a právní předpis správního úřadu se vyhlašuji jejich zveřejněním ve Sbirce právnich předpisů (§ 2 ods. 1).

Právní predpis územního samosprávného celku a právní predpis správního úřadu nabývají platnosti jejich vyhlášením podle $\S 2$ (§ 4 ods. 1).

6

Pri príprave ústavného zákona č. 227/2002 Z. z. o bezpečnosti štátu v čase vojny, vojnového stavu, výnimočného stavu a núdzového stavu sa nepredpokladal takýto druh katastrofálnej situácie, akou pandémia nesporne je. Preto treba seriózne preskúmat' ústavnoprávnu úpravu riešenia problémov, súvisiacich s pandémiou COVID-19. Základnou otázkou je, či súčasný ústavnoprávny stav vyhlasovania núdzového stavu postačuje. Do úvahy prichádza alternatíva, aby vyhlásenie núdzového stavu potvrdzoval Ústavný súd v skrátenom konaní. ${ }^{17}$

Bolo by vhodné precizovat' ústavnoprávne podmienky na ukladanie povinností v zmysle čl. 13 ústavy, ${ }^{18}$ resp. pre strpenie sankcií za nepodriadenie sa dobrovol'nému testovaniu, aj ked’ na základe čl. 5 ods. 3 písm. g) ústavného zákona č. 227/2002 Z. z. napr. ,Vláda obmedzuje [...] slobodu pohybu a pobytu zákazom vychádzania od 9. novembra 2020 do 14. novembra 2020 v čase od 05.00 hod. do 01.00 hod. nasledujúceho dňa, toto obmedzenie sa nevzt'ahuje na [...] osobu, ktorá sa preukáže potvrdením o negatívnom výsledku RT-PCR testu vykonaným od 7. novembra 2020 do 8. novembra 2020 alebo certifikátom .... "19 Zdá sa, že súčasná aplikácia práva v tejto oblasti znovu výrazne otvára problematiku ukladania povinností zákonom, resp. ukladania povinností na základe zákona, $v$ jeho medziach a pri zachovávaní základných práv a slobôd. V takej citlivej situácii, akou je zápas s pandémiou, je vhodné častejšie využívat' ukladanie povinností zákonom, resp. povinností strpiet' sankcie, obdobne ako je to napr. v čl. 5 ods. 3 ústavného zákona č. 227/2002 Z. z. o bezpečnosti štátu v čase vojny, vojnového stavu, výnimočného stavu a núdzového stavu. V prípade ukladania povinností na základe záko-

${ }^{17}$ Tak aj P. RYCHETSKÝ, predseda Ústavného súdu Českej republiky v rozhovore pre ČT24, 21. novembra 2020 https:/ct24.ceskatelevize.cz/domaci/3233632-omezeni-svobody-pohybu-a-podnikani-brutalne-zasahlo-dolidskych-prav-rika-rychetsky (20. január 2021); SLÁDEČEK, V. Vláda a nouzový stav. In Správní právo, 2020, č. $5-6$, s. 279.

${ }^{18}$ Bližšie napr. HENČEKOVÁ, S. Analýza právnej povahy uznesení vlády v súvislosti s núdzovým stavom. In Denník N, 27. december 2020 https://dennikn.sk/blog/2202652/analyza-pravnej-povahy-uznesenivlady-v-suvislosti-s-nudzovym-stavom/ (23. január 2021).

${ }^{19}$ Bližšie uznesenie vlády Slovenskej republiky č. 704 zo 4. novembra 2020 k návrhu na d’alšie rozšírenie opatrení v rámci vyhláseného núdzového stavu podl’a čl. 5 ústavného zákona č. 227/2002 Z. z. o bezpečnosti štátu v čase vojny, vojnového stavu, výnimočného stavu a núdzového stavu v znení neskorších predpisov vyhláseného uznesením vlády Slovenskej republiky č. 587 z 30. septembra 2020. 
na je, z hl'adiska koncepcie právneho štátu, nevyhnutné výraznejšie rešpektovat' dodržiavanie „medzí zákona a zachovávanie základných práv a slobôd“ vrátane kontroly.

Otázne je, či by stačilo novelizovat’ ústavný zákon o bezpečnosti štátu v čase vojny, vojnového stavu, výnimočného stavu a núdzového stavu, alebo je vhodnejšie pripravit' samostatný ústavný zákon upravujúci pandemickú problematiku. ${ }^{20}$ Osobitný ústavný zákon by mohol zohl'adnil temer ročnú skúsenost's pandémiou a pripravit' ústavnoprávny základ, napr. na vydávanie predpisov nižšej právnej sily a eventuálne by, pri dodržaní zásady lege artis, „konvalidoval“ drobné nedostatky. Do úvahy prichádza i obmedzená účinnost' takéhoto ústavného zákona (sunset law). Pri jeho príprave by bolo možné využit' podnety zo zahraničia. ${ }^{21}$

Príkladom takéhoto právneho predpisu je český zákon č. 350/2020 Sb. o zvláštních zpuisobech hlasování ve volbách do zastupitelstev krajů a do Senátu v roce 2020. Zákon upravil právo osôb obmedzených na osobnej slobode kvôli ochrane verejného zdravia pred ochorením Covid-19 volit' vo vol'bách do zastupitel'stiev krajov a do Senátu, ktoré sa uskutočnili 2. a 3. októbra 2020 a 9. a 10. októbra 2020 a v miestnom alebo krajskom referende konanom súčasne $\mathrm{s}$ vol'bami a podmienky výkonu volebného práva a práva hlasovat' $v$ referende týchto osôb prostredníctvom zvláštnych spôsobov hlasovania. Tento zákon upravil aj zvláštne pravidlá správy volieb a zist’ovania výsledkov volieb $(\S 1)$. Pozoruhodné je ustanovenie zákona: „U jednání nezbytných $k$ výkonu volebního práva podle tohoto zákona je vyloučena jejich protiprávnost" (§ 27 ods. 14).

\section{7}

„Slovenská republika je zvrchovaný, demokratický a právny štát“ (čl. 1 ods. 1 prvá veta ústavy). Z tejto ústavnoprávnej normy, v kontexte traktovanej problematiky, minimálne vyplývajú požiadavky úcty $\mathrm{k}$ právam človeka a občana a ukladania povinností prostredníctvom zákonných, zrozumitel’ných, verejne diskutovaných, riadne odôvodne-

${ }^{20}$ BLAIR, T. This is not even the end of the beginning - we need a completely new approach to Covid- 19 . In Independent, 28. január 2021 https://www.independent.co.uk/voices/tony-blair-covid-uk-vaccine-b1794135. html (5. február 2021); BERANOVÁ, K. Vláda nemá dokola žádat o prodloužení nouzového stavu, tvrdí ústavní právníci. In Novinky.cz, 6. február 2001 https:/www.novinky.cz/domaci/clanek/vlada-nema-dokolazadat-o-prodlouzeni-nouzoveho-stavu-tvrdi-ustavni-pravnici-40350118\#utm_content=ribbonnews\&utm term $=$ vl $\% \mathrm{C} 3 \% \mathrm{~A} 1 \mathrm{da} \% 20$ nem $\% \mathrm{C} 3 \% \mathrm{~A} 1 \% 20$ dokola $\% 20 \% \mathrm{C} 5 \% \mathrm{BE} \% \mathrm{C} 3 \% \mathrm{~A} 1$ dat $\& u$ utm_medium $=$ hint $\& u$ ut $_{-}$ source=search.seznam.cz (6. február 2001).

${ }^{21}$ Súhrn stanovísk a správ Benátskej komisie k núdzovému stavu, CDL-PI(2020)003, Štrasburg 16. apríla 2020; Predbežná správa o opatreniach prijatých v členských štátoch Európskej únie v dôsledku krízy COVID-19 a ich vplyv na demokraciu, právny štát a základné práva, Benátska komisia, CDL(2020)018, Štrasburg, 8. október 2020; Núdzový stav v reakcii na krízu koronavírusu: situácia v niektorých členských štátoch I, II a III https://www.ustavnysud.sk/ine-zahranicne-institucie (5. február 2021); Stanovisko č. 995/2020; Uznesenie Európskeho parlamentu z 13. novembra 2020 o vplyve opatrení súvisiacich s pandémiou COVID-19 na demokraciu, právny štát a základné práva (2020/2790(RSP)); WINTR, J. K ústavnosti a zákonnosti protiepidemických opatření na jaře 2020. In Správní právo, 2020, č. 5 - 6, s. 282-297 a tam citovaná literatúra; SLÁDEČEK, V., dielo cit v pozn. č. 17, s. 266-281 a tam citovaná literatúra; SOVA, A. Přezkum opatření přijatých v době nouzového stavu. In Správní právo, 2020, č. 5 - 6, s. 298-312 a tam citovaná literatúra; KR̆EPELKA, F. Právo pandemie Covidu-19: náčrt celkového obrazu. In Časopis zdravotníckeho práva a bioetiky, 2020, No 2, s. 1-70 a tam citovaná literatúra; ONDŘEJEK, P. Proporcionalita opatření přijímaných ve výjimečných stavech. In Časopis pro právní védu a praxi, 2020, č. 4, s. 613-629 a tam citovaná literatúra. 
ných a súdne kontrolovatel’ných aktov v súlade s ústavou i Listinou základných práv a slobôd. ${ }^{22}$

Napriek tomu ,za posledných devät’ mesiacov si bojom proti pandémii vláda vybudovala reputáciu orgánu, ktorý si nerobí príliš t’ažkú hlavu z ústavných poistiek proti zneužitiu moci: bezmála polovicu roka 2020 sme prežili v núdzovom stave; povinnosti, ktorých plnenie mnohých oberá o živobytie či slušné vzdelanie, už nehl'adáme v Zbierke zákonov SR, ale kade-tade po úradných výveskách a vládnych vestníkoch; červené čiary, ktoré štát nesmie za žiadnych okolností prekročit', sa rozplynuli v rozl'ahlých oblastiach vágneho výrazu »primerané opatrenie«“".23

Poznatky z praxe okrem iného kritizujú situáciu, že v nariadeniach vlády a „hygieny“ je t’ažké sa vyznat', l'udia sa v nich strácajú a malé obce nemajú šancu ich analyzovat'. „Na právnom oddelení máme troch l’udí a jedna právnička pre nás takmer na plný úväzok sleduje všetky zmeny v nariadeniach a posiela nám z nich každý deň ,výcuc‘."24 Je zrejmé, že súčasná situácia si vyžaduje osobitne náročnú koncentráciu na riešenie nahromadených problémov (aj) preto, že popri prebiehajúcej pandémie vírusu hrozí i pandémia podávania žalôb a st’ažností.

\section{Literatúra}

BERANOVÁ, K. Vláda nemá dokola žádat o prodloužení nouzového stavu, tvrdí ústavní právníci. In Novinky. cz, 6. február 2001 https://www.novinky.cz/domaci/clanek/vlada-nema-dokola-zadat-o-prodlouzeni-nouzoveho-stavu-tvrdi-ustavni-pravnici-40350118\#utm_content=ribbonnews\&utm_term=vl\%C3\%A$1 \mathrm{da} \% 20$ nem $\% \mathrm{C} 3 \% \mathrm{~A} 1 \% 20$ dokola $\% 20 \% \mathrm{C} 5 \% \mathrm{BE} \% \mathrm{C} 3 \% \mathrm{~A} 1$ dat\&utm_medium $=$ hint\&utm_source $=$ search. seznam.cz

BLAIR, T. This is not even the end of the beginning - we need a completely new approach to Covid-19. In Independent, 28. január 2021 https://www.independent.co.uk/voices/tony-blair-covid-uk-vaccine-b1794135.html

CVRČEK, F. - NOVÁK, F. a kol. Legislativa. Teoretická východiska a problémy. Plzeň : Aleš Čeněk, 2017, s. 55

DRGONEC, J. Ústava Slovenskej republiky: teória a prax. Bratislava : C. H. Beck, 2015

GEHREROVÁ, R. Starosta Rače Drotován: Testovanie sa nám l'ahšie organizuje bez pomoci štátu, vojakov nepotrebujeme. In Denník N, 23. január 2021 https://dennikn.sk/2238782/starosta-race-drotovan-testovanie-sa-nam-lahsie-organizuje-bez-pomoci-statu-vojakov-nepotrebujeme/?ref=mpm

${ }^{22}$ WINTR, J., dielo cit. v pozn. 21, s. 297.

${ }^{23}$ KÁČER, M. Kto má právo posledného slova pri zmene ústavy? In Denník N, 30. november 2020 https:// dennikn.sk/2165002/kto-ma-pravo-posledneho-slova-pri-zmene-ustavy/?ref=list (15. január 2021).

${ }^{24}$ GEHREROVÁ, R. Starosta Rače Drotován: Testovanie sa nám l’ahšie organizuje bez pomoci štátu, vojakov nepotrebujeme. In Dennik N, 23. január 2021 https://dennikn.sk/2238782/starosta-race-drotovantestovanie-sa-nam-lahsie-organizuje-bez-pomoci-statu-vojakov-nepotrebujeme/?ref=mpm (23. január 2021); d’alej napr. MEDVEC, J. Žaloby na pandémiu sú už na súde. In Hospodárske noviny, 18. august 2020, s. 14; MIŠKOVIČ, D. Vládny plán s karanténou má právne trhliny. In Denník N, 21. október 2020, s. 3; TKAČENKO, P. Hygienik môže všetko. In SME, 14. december 2020, s. 8; MIKUŠOVIČ, D. - FOLENTOVÁ, V. Vláda pripravila seniorom rébus: Na poštu môžu íst' bez testu, ak ide o dôchodok, ale list pošlú len s testom. In Denník $N$, 21. január 2021 https://dennikn.sk/2236096/vlada-pripravila-seniorom-rebus-na-postu-mozu-ist-bez-testuak-ide-o-dochodok-list-poslu-len-s-testom/?ref=suv (23. január 2021); Newsfilter: V parlamente opät' úradujú legislatívni amatéri, podcast 02:29 - 04:48, https://dennikn.sk/2236088/newsfilter-v-parlamente-opat-uradujulegislativni-amateri-21-01-2021/?ref=suv (23. január 2021). 
HAVELKOVÁ, M. Opatrení nie je nikdy dost' (3. čast' série blogov k metódam a formám činnosti verejnej správy). In Comenius blog, 2020 https://comeniusblog.flaw.uniba.sk/2020/05/29/opatreni-nie-je-nikdy-dost-3-cast-serie-blogov-k-metodam-a-formam-cinnosti-verejnej-spravy/

HENČEKOVÁ, S. Analýza právnej povahy uznesení vlády v súvislosti s núdzovým stavom https://dennikn.sk/ blog/2202652/analyza-pravnej-povahy-uzneseni-vlady-v-suvislosti-s-nudzovym-stavom/

HODÁS, M. Dopady normotvorby Európskej únie na normotvorbu členského štátu Európskej únie z hl'adiska legislatívnej techniky a normotvorných procesov. Bratislava : Univerzita Komenského, Právnická fakulta 2018.

KÁČER, M. Kto má právo posledného slova pri zmene ústavy? In Denník N, 30. november 2020 https://dennikn.sk/2165002/kto-ma-pravo-posledneho-slova-pri-zmene-ustavy/?ref=list

KNAPP, V. Teorie práva. Praha : C. H. Beck, 1995

KŘEPELKA, F. Právo pandemie Covidu-19: náčrt celkového obrazu. In Časopis zdravotníckeho práva a bioetiky, 2020, No 2

MÁČAJ, L. - CHROPOVSKÝ, P. Niekol'ko úvah o právnych aspektoch opatrení v boji proti pandémii Covid-19, prednáška, Naděje právní vědy 2020 - Právní věda v praxi : mezinárodní konference mladých vědeckých pracovníků konaná on-line dne 27. listopadu 2020

MEDVEC, J. Žaloby na pandémiu sú už na súde. In Hospodárske noviny, 18. august 2020

MIKUŠOVIČ, D. - FOLENTOVÁ, V. Vláda pripravila seniorom rébus: Na poštu môžu íst’ bez testu, ak ide o dôchodok, ale list pošlú len s testom. In Denník N, 21. január 2021 https://dennikn.sk/2236096/vlada-pripravila-seniorom-rebus-na-postu-mozu-ist-bez-testu-ak-ide-o-dochodok-list-poslu-len-s-testom/?re$\mathrm{f}=$ suv

MIŠKOVIČ, D. Vládny plán s karanténou má právne trhliny. In Denník N, 21. október 2020

ONDŘEJEK, P. Proporcionalita opatření přijímaných ve výjimečných stavech. In Časopis pro právní vědu a praxi, 2020, č. 4

PLACHÝ, J. Úloha Sbírky zákonů při publikaci právních aktů moci výkonné. In Časopis pro právní vědu a praxi, 2015, č. 2

RYCHETSKÝ, P., predseda Ústavného súdu Českej republiky v rozhovore pre ČT24, 21. novembra 2020 https://ct24.ceskatelevize.cz/domaci/3233632-omezeni-svobody-pohybu-a-podnikani-brutalne-zasahlo-do-lidskych-prav-rika-rychetsky

SLÁDEČEK, V. Vláda a nouzový stav. In Správní právo, 2020, č. 5 - 6, s. 279

Slovník veřejného práva československého. Svazek I. Reprint původního vydání. Praha : Eurolex Bohemia, 2000

SOVA, A. Přezkum opatření přijatých v době nouzového stavu. In Správní právo, 2020, č. 5 - 6

STAŠA, J. Rozhodnutí a/nebo opatření jako ,předmet“ obecné správní žaloby. In Nový Správny súdny poriadok: návrh. Bratislava : Univerzita Komenského, Právnická fakulta, 2014

STAŠA, J. Nad významy termínu „opatření“ v předpisech správního práva. In Právní rozhledy, 2017, č. 22

TKAČENKO, P. Hygienik môže všetko. In SME, 14. december 2020

WINTR, J. K ústavnosti a zákonnosti protiepidemických opatření na jaře 2020. In Správní právo, 2020, č. 5 -6

*

Ústava Slovenskej republiky

Ústavný zákona č. 227/2002 Z. z. o bezpečnosti štátu v čase vojny, vojnového stavu, výnimočného stavu a núdzového stavu

Zákon č. 355/2007 Z. z. o ochrane, podpore a rozvoji verejného zdravia a o zmene a doplnení niektorých zákonov

Zákon č. 400/2015 Z. z. o tvorbe právnych predpisov a o Zbierke zákonov Slovenskej republiky a o zmene a doplnení niektorých zákonov v znení neskorších predpisov.

Zákon č. 180/2013 Z. z. o organizácii miestnej štátnej správy a o zmene a doplnení niektorých zákonov

Zákon č. 566/1992 Zb. o Národnej banke Slovenska

Zákon č. 308/2000 Z. z. o vysielaní a retransmisii a o zmene zákona č. 195/2000 Z. z. o telekomunikáciách

Zákon č. 278/1993 Z. z. o správe majetku štátu 
Zákon č. 350/2020 Sb. o zvláštních způsobech hlasování ve volbách do zastupitelstev krajů a do Senátu v roce 2020

Zákon č. 35/2021 Sb. o Sbírce právních předpisů územních samosprávných celků a některých správních úřadů Zákon č. 36/2001 Sb., kterým se mění některé zákony v souvislosti s přijetím zákona o Sbírce právních předpisů územních samosprávných celků a některých správních úradů

Uznesenie vlády Slovenskej republiky č. 145 z 26. marca 2014 k návrhu zásad vydávania Vestníka vlády Slovenskej republiky

Uznesenie vlády Slovenskej republiky č. 704 zo 4. novembra 2020 k návrhu na d’alšie rozšírenie opatrení v rámci vyhláseného núdzového stavu podl'a čl. 5 ústavného zákona č. 227/2002 Z. z. o bezpečnosti štátu v čase vojny, vojnového stavu, výnimočného stavu a núdzového stavu v znení neskorších predpisov vyhláseného uznesením vlády Slovenskej republiky č. 587 z 30. septembra 2020.

Upozornenie prokurátora na nezákonný postup orgánu verejnej správy, č. VI/3 Gd 174/20/1000-16, z 29. septembra 2020

Informácia o 38. zasadnutí Rady vlády Slovenskej republiky pre l’udské práva, národnostné menšiny a rodovú rovnost' https://rokovania.gov.sk/RVL/Material/25497/1

Uznesenie Európskeho parlamentu z 13. novembra 2020 o vplyve opatrení súvisiacich s pandémiou COVID-19 na demokraciu, právny štát a základné práva (2020/2790(RSP))

Súhrn stanovísk a správ Benátskej komisie k núdzovému stavu, CDL-PI(2020)003, Štrasburg 16. apríla 2020

Predbežná správa o opatreniach prijatých v členských štátoch Európskej únie v dôsledku krízy COVID-19 a ich vplyv na demokraciu, právny štát a základné práva, Benátska komisia, CDL(2020)018, Štrasburg, 8. október 2020, Stanovisko č. 995/2020

Núdzový stav v reakcii na krízu koronavírusu: situácia v niektorých členských štátoch I, II a III https://www. ustavnysud.sk/ine-zahranicne-institucie 